\title{
The outcome of tuberculosis treatment in subjects with chronic kidney disease in Brazil: a multinomial analysis*
}

\author{
Desfecho do tratamento da tuberculose em indivíduos com doença renal \\ crônica no Brasil: uma análise multinomial \\ Barbara Reis-Santos, Teresa Gomes, Bernardo Lessa Horta, \\ Ethel Leonor Noia Maciel
}

\begin{abstract}
Objective: To analyze the association between clinical/epidemiological characteristics and outcomes of tuberculosis treatment in patients with concomitant tuberculosis and chronic kidney disease (CKD) in Brazil. Methods: We used the Brazilian Ministry of Health National Case Registry Database to identify patients with tuberculosis and CKD, treated between 2007 and 2011. The tuberculosis treatment outcomes were compared with epidemiological and clinical characteristics of the subjects using a hierarchical multinomial logistic regression model, in which cure was the reference outcome. Results: The prevalence of CKD among patients with tuberculosis was $0.4 \%$ (95\% Cl: $0.37-0.42 \%)$. The sample comprised 1,077 subjects. The outcomes were cure, in 58\%; treatment abandonment, in 7\%; death from tuberculosis, in 13\%; and death from other causes, in $22 \%$. The characteristics that differentiated the 0Rs for treatment abandonment or death were age; alcoholism; AIDS; previous noncompliance with treatment; transfer to another facility; suspected tuberculosis on chest X-ray; positive results in the first smear microscopy; and indications for/use of directly observed treatment, short-course strategy. Conclusions: Our data indicate the importance of sociodemographic characteristics for the diagnosis of tuberculosis in patients with CKD and underscore the need for tuberculosis control strategies targeting patients with chronic noncommunicable diseases, such as CKD.
\end{abstract}

Keywords: Tuberculosis/epidemiology; Renal insufficiency, chronic/epidemiology; Risk factors; Logistic models.

\section{Resumo}

Objetivo: Analisar a associação de características clínicas e epidemiológicas de indivíduos com tuberculose e doença renal crônica (DRC) com os desfechos do tratamento da tuberculose no Brasil. Métodos: Entre 2007 e 2011, foram selecionados indivíduos com DRC e tuberculose utilizando o Sistema de Informação de Agravos de Notificação do Ministério da Saúde do Brasil. Foram comparados os desfechos do tratamento da tuberculose com características clínicas e epidemiológicas dos pacientes por um modelo hierárquico de regressão logística multinomial, no qual cura foi o desfecho de referência. Resultados: A prevalência de DRC entre os casos de tuberculose foi de 0,4\% (1C95\%: 0,37-0,42\%). A amostra incluiu 1.077 indivíduos, cujos desfechos do tratamento da tuberculose foram os seguintes: cura, em 58\%; abandono do tratamento, em 7\%; óbito por tuberculose, em 13\%; e óbito por outras causas, em 22\%. As características que diferenciam as OR de abandono do tratamento e de óbito foram idade; alcoolismo; AIDS; abandono prévio; transferência para outra unidade de tratamento; suspeita de tuberculose em radiografia de tórax; baciloscopia inicial positiva; e indicação ou realização de tratamento diretamente observado. Conclusões: Os dados apontam para a importância das características sociodemográficas na determinação da tuberculose em indivíduos com DRC e reforçam a necessidade de estratégias de controle da tuberculose direcionadas a pacientes com doenças crônicas não transmissíveis, como a DRC.

Descritores: Tuberculose/epidemiologia; Insuficiência renal crônica/epidemiologia; Fatores de risco; Modelos logísticos.

\footnotetext{
* Study carried out at the Epidemiology Laboratory, Federal University of Espírito Santo, Vitória, Brazil. Correspondence to: Ethel Leonor Noia Maciel, Avenida Marechal Campos, 1468, Maruípe, CEP 29040-091, Vitória, ES, Brasil. Tel/Fax: 5527 3335-7287. E-mail: ethel.maciel@gmail.com

Financial support: This study received financial support from the Conselho Nacional de Desenvolvimento Científico e Tecnológico (CNPq, National Council for Scientific and Technological Development) - Estudo de Doenças Negligenciadas-2006 (Neglected Diseases Study-2006) and Edital Universal-2009 (Universal Mandate-2009), as well as from the International Clinical Operational and Health Services Research and Training Award, Grant no. ICOHRTA 5 U2R TW006883-02.

Submitted: 15 December 2012. Accepted, after review: 22 July 2013.
} 


\section{Introduction}

Chronic kidney disease (CKD) is already considered a pandemic.(1) In view of the radical changes in habits and lifestyle, as well as of the aging of the population, all of which occurred mainly in the late 20th century and early 21st century, the rates of CKD-related morbidity and mortality have increased significantly and are expected to continue to grow in the years to come. ${ }^{(1,2)}$

Patients with CKD have a weakened immune system as a result of the chronic inflammatory state caused by renal replacement therapies, as well as of CKD itself and other comorbidities. ${ }^{(3)}$ Therefore, patients with CKD, regardless of being on renal replacement therapy, are more susceptible to infectious diseases, ${ }^{(4)}$ among which is tuberculosis.

Tuberculosis is also recognized as a global public health problem, the control of which has been a challenge to various governmental and non-governmental organizations worldwide. ${ }^{(5,6)}$ In recent years, Brazil has seen a decrease in the number of tuberculosis cases, in tuberculosis incidence rates, and in mortality from tuberculosis. The country has also made advances in the detection of the disease and in the management of cases of co-infection with HIV and drug resistance. However, there are still major obstacles that make it impossible for Brazil to eliminate tuberculosis, such as limitations in contact investigation and in diagnosing tuberculosis in primary care, as well as the low cure rate among the patients treated. ${ }^{(7,8)}$

Patients with CKD are recognized to be at increased risk for tuberculosis and, because of their state of immunosuppression, they also have poor outcomes during treatment..$^{(5)}$ In Brazil, there is a large and growing population of subjects with chronic noncommunicable diseases, among which is CKD, as well as a high prevalence of tuberculosis in the general population and in high-risk groups. ${ }^{(9,10)}$

Therefore, in view of the convergence of these two pandemics and the evidence of occurrence of poor outcomes in this population, we believe that investigations on the subject have not yet been exhausted and that studies are needed to identify the characteristics related to unfavorable outcomes, taking the differences among the possible outcomes into consideration, given that such outcomes imply control measures with different degrees of complexity.
The objective of the present study was to examine the association between clinical/ epidemiological characteristics and outcomes of tuberculosis treatment in patients with concomitant tuberculosis and CKD by using multivariate analysis and multinomial logistic regression.

\section{Methods}

The Sistema de Informação de Agravos de Notificação (SINAN, National Case Registry Database) is one of the health surveillance systems of Brazil, having been developed in the 1990s with the purpose of collecting and disseminating information that, in cases of tuberculosis, include sociodemographic data, health history, and characteristics of the disease and its treatment. ${ }^{(11)}$ Analysis of completeness and quality of the information generated have been carried out over the years, this database being considered an important and reliable source of information. ${ }^{(12)}$

Between 2007 and 2011, a total of 432,958 tuberculosis cases were reported to the SINAN in Brazil, and of those patients, 1,716 were reported as also having CKD (TB-CKD). Therefore, tuberculosis treatment outcomes (cure, treatment abandonment, death from tuberculosis, and death from other causes) were compared with clinical/epidemiological characteristics in TB-CKD patients. The TB-CKD patients for whom treatment completion status was inconclusive (unknown, transfer, or change in diagnosis) or who developed multidrug resistant tuberculosis were excluded from the study.

A TB-CKD patient was defined as that for whom the field called "other comorbidities" in the SINAN database was filled with words describing CKD, regardless of its stage. Therefore, the following descriptions were found and included: chronic kidney disease; chronic renal failure; chronic nephropathy; chronic glomerulonephritis; chronic renal patient; hemodialysis; renal transplantation; kidney transplantation; dialysis-induced renal failure; and renal patient on dialysis.

The sociodemographic variables were as follows: gender (female/male); age $(<20$ years $/ 20-39$ years $/ 40-59$ years $/ \geq 60$ years); race (White/Black/Mulatto/others); years of schooling (0 years [illiterate]/1-4 years/5-8 years/9-12 years/> 12 years/not applicable); residence (urban or peri-urban/rural); and 
institutionalization (no/prison/nursing home/ orphanage/psychiatric hospital/others).

Health history included presence/absence of alcoholism, diabetes mellitus, mental illness, AIDS, and renal transplantation. In addition, we analyzed the following variables related to the characteristics of tuberculosis and its treatment: type of case (new case/recurrence/readmission after treatment abandonment/transfer); tuberculin skin testing (negative/weakly positive/strongly positive); chest X-ray (normal/suspicious); initial smear (sputum or other samples; negative/positive); follow-up smear at 2 months (sputum; negative/ positive); culture (sputum or other samples; negative/positive); histopathological examination (positive for AFB/suggestive of tuberculosis/ not suggestive of tuberculosis); presentation of tuberculosis (pulmonary/extrapulmonary/ pulmonary + extrapulmonary); occupational disease (yes/no); indications for directly observed treatment, short-course strategy (DOTS; yes/no); and use of DOTS (yes/no).

Proportions were compared with Pearson's chi-square test or the likelihood ratio, and the variables associated with the outcome of interest $(p<0.10)$ were included in the hierarchical multinomial logistic regression model. Multinomial logistic regression is useful for modeling probabilities of multiple category outcomes simultaneously. ${ }^{(13)}$ In the present analysis, "cure" was the reference category for the response variable, being compared with the other categories (cure vs. treatment abandonment; cure vs. death from tuberculosis; and cure vs. death from other causes).

On the basis of a conceptual model for the diagnosis of tuberculosis ${ }^{(14)}$ and to account for the interrelationships among the determinants of tuberculosis, ${ }^{(15)}$ we defined three hierarchical levels: level 1, sociodemographic variables; level 2, variables kept at level $1(p<0.10)$ and comorbidities; and level 3, variables kept at level $2(p<0.10)$ and variables related to the characteristics of tuberculosis. Results are expressed as $\mathrm{OR}$ and $95 \% \mathrm{Cl}$. The analyses were performed with the STATA statistical program, version 12.0 (StataCorp LP, College Station, TX, USA).

The present study was approved by the Research Ethics Committee of the Federal University of Espírito Santo Health Sciences Center (Protocol no. 121/06).

\section{Results}

Between 2007 and 2011, the prevalence of CKD among the tuberculosis cases reported to the SINAN was $0.4 \%$ (95\% Cl: 0.37-0.42\%).

In the present study, 1,077 TB-CKD patients were evaluated. The outcomes in this sample were as follows: cure, in 628 patients (58.3\%); treatment abandonment, in $79(7.4 \%)$; death from tuberculosis, in 137 (12.7\%); and death from other causes, in 233 (21.6\%). Only 1 patient developed multidrug resistant tuberculosis and was therefore excluded from the subsequent analyses. We also excluded 638 patients with the following outcomes: unknown, in 476; transfer, in 145; and change in diagnosis, in 17.

The proportion of patients classified as cured after tuberculosis treatment was lower among those aged 60 years or older $(p<0.001)$. In contrast, no significant differences were found in the distribution of gender, race, level of education, or residence for each outcome (Table 1).

Table 2 shows that death from tuberculosis and death from other causes were high among patients identified as alcoholics $(24.1 \%$ and $31.0 \%$, respectively). Diabetes mellitus, mental illness, and AIDS were less prevalent comorbidities among those who achieved cure.

The main clinical characteristics of tuberculosis and its treatment can be found in Table 3 .

Among those patients who were readmitted to treatment after having abandoned it, the outcomes were cure, in $22.6 \%$; treatment abandonment, in 32.2\%; death from tuberculosis, in 22.6\%; and death from other causes, in $22.6 \%(p<0.001)$.

Significant differences were found in the distribution of disease presentation among the treatment outcomes $(p=0.004)$. The proportion of patients with concomitant pulmonary and extrapulmonary tuberculosis among those who were cured (46.4\%) was lower than was that of patients with pulmonary tuberculosis and that of patients with extrapulmonary tuberculosis (58.4\% and $60.4 \%$, respectively).

There was a difference in the distribution of proportions for indications for and for use of DOTS ( $p=0.005$ and $p=0.029$, respectively).

For the multivariate analysis and multinomial logistic regression, the hierarchical model was defined as follows: level 1, age; level 2, diabetes, alcoholism, mental illness, AIDS, and renal transplantation; and level 3, type of case, 
chest X-ray, initial smear, disease presentation, indications for DOTS, and use of DOTS. The tuberculin skin test variable, although statistically significant, was not included in the model because of the low proportion of tests performed.

The main findings of this analysis can be found in Table 4. The OR for treatment abandonment in relation to cure was found to be lower in TB-CKD patients aged 60 years or older $(\mathrm{OR}=0.28 ; 95 \% \mathrm{Cl}: 0.10-0.74)$ than in those younger than 20. Alcoholism was associated with death from tuberculosis in relation to cure $(\mathrm{OR}=3.38 ; 95 \% \mathrm{Cl}: 1.63-6.97)$ and with death from other causes in relation to cure $(O R=2.30$; 95\% Cl: 1.18-4.47). The presence of AIDS was also associated with death from other causes in relation to cure (OR $=3.32 ; 95 \% \mathrm{Cl}: 1.68-6.58)$.
In cases of readmission after treatment abandonment, as compared with new cases (reference), the OR for abandonment in relation to cure was 16.08 (95\%: 5.41-47.82) and that for death from tuberculosis in relation to cure was 4.82 (95\% Cl: 1.53-15.21).

In patients with indications for DOTS, the OR for abandonment in relation to cure was low $(O R=0.33 ; 95 \% \mathrm{Cl}: 0.12-0.92)$, whereas the $\mathrm{OR}$ for death from other causes in relation to cure was high (OR $=1.71 ; 95 \% \mathrm{Cl}: 1.03-2.85)$. In contrast, in those who received DOTS, the OR for death from tuberculosis in relation to cure was lower ( $\mathrm{OR}=0.44 ; 95 \% \mathrm{Cl}: 0.22-0.90$ ), even after controlling for the other variables included in the model.

Table 1 - Sociodemographic characteristics of patients with chronic kidney disease who are reported as having tuberculosis on the National Case Registry Database, by tuberculosis treatment outcome, Brazil, 2007-2011.

\begin{tabular}{|c|c|c|c|c|c|c|}
\hline \multirow[t]{2}{*}{ Characteristic } & & \multicolumn{4}{|c|}{ Outcome } & \multirow[t]{2}{*}{$p^{*}$} \\
\hline & & Cure & $\begin{array}{c}\text { Treatment } \\
\text { abandonment }\end{array}$ & $\begin{array}{c}\text { Death from } \\
\text { TB }\end{array}$ & $\begin{array}{l}\text { Death from } \\
\text { other causes }\end{array}$ & \\
\hline Gender & $(n=1,077)$ & & & & & \multirow{3}{*}{0.167} \\
\hline Female & & $218(58.6)$ & $35(9.4)$ & $48(12.9)$ & $71(19.1)$ & \\
\hline Male & & $410(58.2)$ & $44(6.2)$ & 89 (12.6) & $162(23.0)$ & \\
\hline Age, years & $(n=1,076)$ & & & & & \\
\hline$<20$ & & $16(57.2)$ & $8(28.6)$ & $2(7.1)$ & $2(7.1)$ & \multirow{4}{*}{$<0.001$} \\
\hline $20-39$ & & $184(67.7)$ & $25(9.2)$ & $20(7.3)$ & $43(15.8)$ & \\
\hline $40-59$ & & 299 (59.9) & $28(5.6)$ & $64(12.8)$ & $108(21.7)$ & \\
\hline$\geq 60$ & & $129(46.6)$ & $18(6.5)$ & $50(18.0)$ & $80(28.9)$ & \\
\hline Race & $(n=968)$ & & & & & \multirow{5}{*}{0.438} \\
\hline White & & $291(60.8)$ & $30(6.3)$ & $50(10.4)$ & $108(22.5)$ & \\
\hline Black & & $100(60.6)$ & $15(9.1)$ & $19(11.5)$ & $31(18.8)$ & \\
\hline Mulatto & & $173(55.5)$ & $21(6.7)$ & $46(14.7)$ & $72(23.1)$ & \\
\hline Others & & 7 (58.3) & $0(0.0)$ & $3(25.0)$ & $2(16.7)$ & \\
\hline Years of schooling & $(n=610)$ & & & & & \\
\hline 0 (illiterate) & & $21(60.0)$ & $3(8.6)$ & $4(11.4)$ & $7(20.0)$ & \multirow{6}{*}{0.770} \\
\hline $1-4$ & & $122(59.8)$ & $15(7.4)$ & 25 (12.2) & $42(20.6)$ & \\
\hline $5-8$ & & $114(62.0)$ & $17(9.2)$ & $17(9.2)$ & 36 (19.6) & \\
\hline $9-12$ & & $76(66.1)$ & $8(7.0)$ & $13(11.3)$ & $18(15.6)$ & \\
\hline$>12$ & & 44 (75.9) & $2(3.4)$ & $4(6.9)$ & $8(13.8)$ & \\
\hline N/A & & $8(57.1)$ & $2(14.3)$ & $0(0.0)$ & $4(28.6)$ & \\
\hline Residence & $(n=816)$ & & & & & \multirow{3}{*}{0.893} \\
\hline Urban & & 455 (59.3) & $59(7.7)$ & $94(12.2)$ & $160(20.8)$ & \\
\hline Rural & & $29(60.4)$ & $4(8.3)$ & $7(14.6)$ & 8 (16.7) & \\
\hline Institutionalization & $(n=1,032)$ & & & & & \\
\hline No & & $580(58.9)$ & $69(7.0)$ & $123(12.5)$ & $213(21.6)$ & \multirow{2}{*}{0.380} \\
\hline Yes & & $25(53.2)$ & $5(10.6)$ & $9(19.2)$ & $8(17.0)$ & \\
\hline
\end{tabular}

TB: tuberculosis. aValues expressed as n (\%). *Pearson's chi-square test. 
The outcome of tuberculosis treatment in subjects with chronic kidney disease in Brazil: a multinomial analysis

Table 2 - Comorbidities of patients with chronic kidney disease who are reported as having tuberculosis on the National Case Registry Database, by tuberculosis treatment outcome, Brazil, 2007-2011. ${ }^{\text {a }}$

\begin{tabular}{|c|c|c|c|c|c|c|}
\hline \multirow[t]{2}{*}{ Characteristic } & & \multicolumn{4}{|c|}{ Outcome } & \multirow[t]{2}{*}{$\mathrm{p}$} \\
\hline & & Cure & $\begin{array}{c}\text { Treatment } \\
\text { abandonment }\end{array}$ & $\begin{array}{c}\text { Death from } \\
\text { TB }\end{array}$ & $\begin{array}{l}\text { Death from } \\
\text { other causes }\end{array}$ & \\
\hline Alcoholism & $(n=969)$ & & & & & \\
\hline No & & $548(60.1)$ & $62(6.8)$ & 108 (11.9) & 193 (21.2) & $0.004^{*}$ \\
\hline Yes & & $24(41.4)$ & $2(3.5)$ & $14(24.1)$ & $18(31.0)$ & \\
\hline Diabetes & $(n=979)$ & & & & & \\
\hline No & & $471(60.8)$ & $48(6.2)$ & 95 (12.3) & $160(20.7)$ & $0.050^{*}$ \\
\hline Yes & & $103(50.2)$ & $18(8.8)$ & $30(14.6)$ & $54(26.3)$ & \\
\hline Mental illness & $(n=965)$ & & & & & \\
\hline No & & 564 (59.2) & $65(6.8)$ & 119 (12.5) & 205 (21.5) & $0.022^{* * *}$ \\
\hline Yes & & 4 (33.3) & $1(8.3)$ & $0(0.0)$ & 7 (58.4) & \\
\hline AIDS & $(n=901)$ & & & & & \\
\hline No & & $512(59.0)$ & $53(6.2)$ & $108(12.7)$ & $181(21.2)$ & $0.016^{*}$ \\
\hline Yes & & $19(40.4)$ & $3(6.4)$ & $6(12.8)$ & $19(40.4)$ & \\
\hline RT & $(\mathrm{N}=1.077)$ & & & & & \\
\hline No & & 493 (56.5) & $68(7.8)$ & 119 (13.7) & $192(22.0)$ & $0.065^{*}$ \\
\hline Yes & & $135(65.8)$ & $11(5.4)$ & $18(8.8)$ & $41(20.0)$ & \\
\hline
\end{tabular}

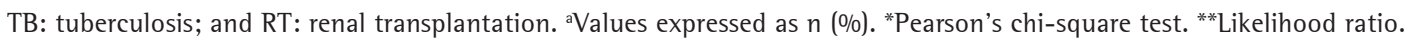

\section{Discussion}

The relationship between tuberculosis and CKD has been studied over the years. ${ }^{(16-18)}$ The higher risk for developing tuberculosis among patients with end-stage CKD has been described in several studies, with this risk being up to 37 times higher in those for whom the mode of renal replacement therapy is transplantation and 10 to 25 times higher in those on hemodialysis. ${ }^{(5,16)}$ However, we know of no studies that have evaluated the prevalence of CKD, regardless of the use of renal replacement therapy, among patients with active tuberculosis.

The fact that associations between tuberculosis, which is a longstanding global public health problem, and CKD, which is one of the new challenges of this century, were evaluated in the present study underscores its importance and relevance. However, some limitations should be considered. The prevalence of TB-CKD patients might have been underestimated because recording this information is not mandatory and depends on patient reporting at the time of registry, and therefore there is the possibility of a classification bias, through which patients with CKD could have been classified as not having CKD. However, it is also important to emphasize that this does not affect the observed associations, given that reporting of CKD is not related to the study variables.

Although studies have emphasized that SINAN is a reliable source of information on tuberculosis, those studies indicate that there are limitations in completeness of variables and that there is underreporting of tuberculosis cases and deaths from tuberculosis. ${ }^{(12,19,20)}$ We also found that there were patients for whom information on some study variables was missing or inconsistent, and we decided not to exclude such variables because of the statistical power of the study.

Our results showed that the characteristics associated with treatment abandonment were age, readmission to treatment after having abandoned it, and indications for DOTS. The characteristics associated with death from tuberculosis were alcoholism, readmission to treatment after having abandoned it, suspected tuberculosis on chest X-ray, and use of DOTS. The characteristics that differentiated the $\mathrm{OR}$ for death from other causes in relation to cure were age, alcoholism, AIDS, transfer to another facility, a positive initial smear, and indications for DOTS. 
Table 3 - Clinical characteristics of patients with chronic kidney disease who are reported as having tuberculosis on the National Case Registry Database, by tuberculosis treatment outcome, Brazil, 2007-2011. ${ }^{\text {a }}$

\begin{tabular}{|c|c|c|c|c|c|c|}
\hline \multicolumn{2}{|l|}{ Characteristic } & \multicolumn{4}{|c|}{ Outcome } & \multirow[t]{2}{*}{$\mathrm{p}$} \\
\hline & & \multirow[t]{2}{*}{ Cure } & \multirow[t]{2}{*}{$\begin{array}{c}\text { Treatment } \\
\text { abandonment }\end{array}$} & \multirow[t]{2}{*}{$\begin{array}{c}\text { Death from } \\
\text { TB }\end{array}$} & \multirow[t]{2}{*}{$\begin{array}{l}\text { Death from } \\
\text { other causes }\end{array}$} & \\
\hline Type of case & $n=1,077)$ & & & & & \multirow{6}{*}{$<0.001^{* * *}$} \\
\hline New case & & $541(58.1)$ & $58(6.2)$ & $120(12.9)$ & $212(22.8)$ & \\
\hline Recurrence & & $30(58.8)$ & 7 (13.7) & $5(9.8)$ & $9(17.7)$ & \\
\hline \multicolumn{2}{|l|}{$\begin{array}{l}\text { Readmission after treatment } \\
\text { abandonment }\end{array}$} & 7 (22.6) & $10(32.2)$ & $7(22.6)$ & $7(22.6)$ & \\
\hline \multicolumn{2}{|l|}{ Unknown } & $1(20.0)$ & $1(20.0)$ & $1(20.0)$ & $2(40.0)$ & \\
\hline \multicolumn{2}{|l|}{ Transfer } & $49(83.0)$ & $3(5.1)$ & $4(6.8)$ & $3(5.1)$ & \\
\hline \multicolumn{2}{|l|}{ Tuberculin skin testing } & & & & & \\
\hline \multicolumn{2}{|l|}{ Negative } & $69(58.0)$ & $8(6.7)$ & $15(12.6)$ & $27(22.7)$ & \\
\hline \multicolumn{2}{|l|}{ Weakly positive } & $14(66.7)$ & $0(0.0)$ & $4(19.0)$ & $3(14.3)$ & $<0.001^{* * *}$ \\
\hline \multicolumn{2}{|l|}{ Strongly positive } & $77(80.2)$ & $10(10.4)$ & $3(3.1)$ & $6(6.3)$ & \\
\hline \multicolumn{2}{|l|}{ Chest X-ray } & & & & & \\
\hline \multirow[t]{2}{*}{ Normal } & & $118(66.3)$ & $15(8.4)$ & $8(4.5)$ & $37(20.8)$ & \multirow{2}{*}{$0.003^{*}$} \\
\hline & & $420(56.4)$ & $57(7.7)$ & $109(14.7)$ & $158(21.2)$ & \\
\hline \multicolumn{2}{|l|}{ Initial SM } & & & & & \\
\hline \multicolumn{2}{|l|}{ Negative } & $178(52.8)$ & $24(7.1)$ & $49(14.5)$ & $86(25.5)$ & \multirow{2}{*}{$0.002^{*}$} \\
\hline Positive & & $215(63.8)$ & $22(6.5)$ & $52(15.4)$ & $48(14.3)$ & \\
\hline \multicolumn{2}{|l|}{ SM at 2 months } & & & & & \\
\hline \multicolumn{2}{|l|}{ Negative } & $118(83.1)$ & $5(3.5)$ & $4(2.8)$ & $15(10.6)$ & \multirow{2}{*}{$0.197^{* *}$} \\
\hline \multicolumn{2}{|l|}{ Positive } & 14 (93.3) & $0(0.0)$ & $1(6.7)$ & $0(0.0)$ & \\
\hline Culture & $(n=247)$ & & & & & \\
\hline Negative & & $61(62.9)$ & $4(4.1)$ & $13(13.4)$ & $19(19.6)$ & 7 $711^{*}$ \\
\hline Positive & & $94(62.7)$ & $11(7.3)$ & $16(10.7)$ & $29(19.3)$ & 0.711 \\
\hline Histopathology & $(n=270)$ & & & & & \\
\hline Positive for AFB & & 39 (70.9) & $1(1.8)$ & $4(7.3)$ & $11(20.0)$ & \\
\hline Suggestive & & $122(61.3)$ & $18(9.1)$ & $15(7.5)$ & $44(22.1)$ & $0.146^{* *}$ \\
\hline Not suggestive & & $7(43.8)$ & $1(6.2)$ & $4(25.0)$ & $4(25.0)$ & \\
\hline Presentation & $V=1.077)$ & & & & & \\
\hline Pulmonary & & $320(58.4)$ & $47(8.6)$ & $79(14.4)$ & $102(18.6)$ & \\
\hline Extrapulmonary & & $269(60.4)$ & $29(6.5)$ & $43(9.7)$ & $104(23.4)$ & $0.004^{*}$ \\
\hline Pulmonary + extrapulmona & nary & $39(46.4)$ & $3(3.6)$ & $15(17.9)$ & $27(32.1)$ & \\
\hline Occupational disease & $(n=692)$ & & & & & \\
\hline No & & $410(59.9)$ & $57(8.3)$ & $81(11.9)$ & $136(19.9)$ & $0260^{* * *}$ \\
\hline Yes & & $3(37.5)$ & $0(0.0)$ & $2(25.0)$ & $3(37.5)$ & 0.200 \\
\hline DOTS-i & $(n=983)$ & & & & & \\
\hline No & & $374(59.4)$ & $59(9.4)$ & 74 (11.7) & $123(19.5)$ & $0005 *$ \\
\hline Yes & & $219(62.0)$ & $12(3.4)$ & 41 (11.6) & $81(23.0)$ & $0.005^{\prime \prime}$ \\
\hline DOTS-u & $(n=850)$ & & & & & \\
\hline No & & $338(59.6)$ & $52(9.2)$ & $67(11.8)$ & $110(19.4)$ & $0029 *$ \\
\hline Yes & & $190(67.1)$ & $12(4.2)$ & $26(9.2)$ & 55 (19.5) & $0.029^{\prime \prime}$ \\
\hline
\end{tabular}

TB: tuberculosis; SM: smear (sputum or other samples); DOTS-i: indications for directly observed treatment, short-

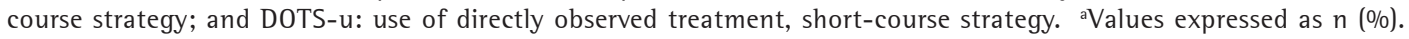
*Pearson's chi-square test. ${ }^{* *}$ Likelihood ratio. 
Table 4 - Multivariate analysis and multinomial logistic regression with a hierarchical model of sociodemographic and clinical covariates associated with tuberculosis treatment outcomes in patients with chronic kidney disease who are reported as having tuberculosis on the National Case Registry Database, by tuberculosis treatment outcome, Brazil, 2007-2011.

\begin{tabular}{|c|c|c|c|c|c|}
\hline Level & Characteristic & & $\begin{array}{l}\text { Cure-treatment } \\
\text { abandonment } \\
\text { OR }(95 \% \mathrm{Cl})\end{array}$ & $\begin{array}{c}\text { Cure-death from } \\
\text { TB } \\
\text { OR }(95 \% \mathrm{Cl})\end{array}$ & $\begin{array}{c}\text { Cure-death from } \\
\text { other causes } \\
\text { OR }(95 \% \mathrm{Cl})\end{array}$ \\
\hline \multirow{4}{*}{1} & Age, years & $<20$ & Ref. & Ref. & Ref. \\
\hline & & $20-39$ & $0.27(0.10-0.70)$ & $0.87(0.19-4.06)$ & $1.87(0.41-8.44)$ \\
\hline & & $40-59$ & $0.19(0.07-0.48)$ & $1.71(0.38-7.63)$ & $2.89(0.65-12.77)$ \\
\hline & & $\geq 60$ & $0.28(0.10-0.74)$ & $3.10(0.69-14.97)$ & $4.96(1.11-22.15)$ \\
\hline \multirow{10}{*}{2} & Diabetes & No & Ref. & Ref. & Ref. \\
\hline & & Yes & $1.76(0.94-3.29)$ & $1.19(0.73-1.93)$ & $1.40(0.94-2.07)$ \\
\hline & Alcoholism & No & Ref. & Ref. & Ref. \\
\hline & & Yes & $0.60(0.13-2.78)$ & 3.38 (1.63-6.97) & $2.30(1.18-4.47)$ \\
\hline & Mental illness & No & Ref. & Ref. & Ref. \\
\hline & & Yes & $1.25(0.10-14.74)$ & $8.19(---)$ & $2.71(0.73-10.08)$ \\
\hline & AIDS & No & Ref. & Ref. & Ref. \\
\hline & & Yes & $1.53(0.43-5.45)$ & $1.74(0.66-4.59)$ & $3.32(1.68-6.58)$ \\
\hline & RT & No & Ref. & Ref. & Ref. \\
\hline & & Yes & $0.64(0.32-1.27)$ & $0.66(0.37-1.15)$ & $0.99(0.66-1.49)$ \\
\hline \multirow{16}{*}{3} & Treatment status & New case & Ref. & Ref. & Ref. \\
\hline & & Recurrence & $2.27(0.91-5.69)$ & $0.96(0.35-2.64)$ & $0.94(0.42-2.10)$ \\
\hline & & $\begin{array}{l}\text { Readmission } \\
\text { after treatment } \\
\text { abandonment }\end{array}$ & $16.08(5.41-47.82)$ & $4.82(1.53-15.21)$ & $2.62(0.86-8.03)$ \\
\hline & & Unknown & $5.41(0.29-99.49)$ & $2.67(0.15-47.80)$ & $4.28(0.36-51.29)$ \\
\hline & & Transfer & $0.61(0.18-2.10)$ & $0.46(0.16-1.36)$ & $0.18(0.05-0.62)$ \\
\hline & Chest X-ray & Normal & Ref. & Ref. & Ref. \\
\hline & & Suspicious & $1.02(0.47-2.20)$ & 3.07 (1.37-6.89) & $1.33(0.82-2.17)$ \\
\hline & Initial SM & Negative & Ref. & Ref. & Ref. \\
\hline & & Positive & $0.69(0.35-1.34)$ & $0.76(0.46-1.23)$ & $0.46(0.29-0.71)$ \\
\hline & Presentation & Pulmonary & Ref. & Ref. & Ref. \\
\hline & & Extrapulmonary & $0.82(0.42-1.60)$ & $1.03(0.61-1.72)$ & $1.21(0.81-1.83)$ \\
\hline & & $\begin{array}{l}\text { Pulmonary + } \\
\text { extrapulmonary }\end{array}$ & $0.56(0.16-2.00)$ & $1.48(0.74-2.96)$ & $1.69(0.94-3.05)$ \\
\hline & DOTS-i & No & Ref. & Ref. & Ref. \\
\hline & & Yes & $0.33(0.12-0.92)$ & $1.54(0.84-2.82)$ & $1.71(1.03-2.85)$ \\
\hline & DOTS-u & No & Ref. & Ref. & Ref. \\
\hline & & Yes & $0.84(0.30-2.37)$ & $0.44(0.22-0.90)$ & $0.57(0.32-1.00)$ \\
\hline
\end{tabular}

TB: tuberculosis; RT: renal transplantation; SM: smear (sputum); DOTS-i: indications for directly observed treatment, short-course strategy; and DOTS-u: use of directly observed treatment, short-course strategy. Hierarchical levels: level 1 (sociodemographic characteristics); level 2 (variables kept at level $1+$ comorbidities); and level 3 (variables kept at level $2+$ characteristics of tuberculosis). 
The association between aging and poor tuberculosis treatment outcomes has been described in previous studies, indicating that potential comorbidities that occur in the aging process play a key role in the prognosis of tuberculosis. ${ }^{(21)}$ The association with death from other causes in relation to cure in those TB-CKD patients aged 60 years or older confirms the importance of comorbidities in this population and suggests the possibility of a bidirectional relationship between tuberculosis and CKD; therefore, CKD affects tuberculosis outcomes as tuberculosis affects CKD outcomes, as is true for other chronic noncommunicable diseases. ${ }^{(22)}$

It is of note that the OR for treatment abandonment in relation to cure was lower for those over 20 years of age. This finding speaks in favor of the quality of care provided by nephrology teams in Brazil, who usually opt for close monitoring of their patients and adopt strategies that promote adherence to conservative treatment, dialysis therapies, or renal transplantation, the positive results of which can be extrapolated to tuberculosis treatment. ${ }^{(23)}$

Alcoholism, which is another important and frequently studied risk factor for tuberculosis, ${ }^{(5,24)}$ also increased the OR for death from tuberculosis and death from other causes in our study, which indicates an urgent need for a change in action strategies aimed at the control of alcoholism, strategies that should be based on measures addressing the social determinants of tuberculosis. ${ }^{(14)}$

Despite the major advances resulting from collaboration between tuberculosis control and HIV/AIDS control programs, ${ }^{(6)}$ HIV infection/ AIDS continues to increase the risk for poor outcomes in patients with tuberculosis, ${ }^{(25)}$ and this was also observed in our study. A recent systematic review and meta-analysis suggests that, for these patients, tuberculosis treatment duration should be extended to more than 8 months in order to improve outcomes. ${ }^{(25)}$

Although we found no statistically significant differences in the distribution of institutionalization among the outcomes, it has been reported that tuberculosis is the leading cause of death in the prison population in developing countries. ${ }^{(26)} \mathrm{In}$ addition, the diagnosis of tuberculosis is usually delayed in these subjects, and adherence to treatment is extremely difficult. ${ }^{(27)}$
In a study conducted in the city of Campinas, Brazil, in the 1990s, the proportions of treatment abandonment and death from tuberculosis were higher among the patients who were readmitted to treatment after having abandoned it than they were among the new cases, a result that is similar to that found in our study. ${ }^{(28)}$

A positive follow-up smear has been associated with unfavorable tuberculosis treatment outcomes. ${ }^{(24)}$ This association was not observed in our study; however, the large number of cases in which follow-up smear microscopy was not performed in our sample, as well as the fact that approximately $40 \%$ of the patients had extrapulmonary tuberculosis and smear positivity rates are lower for this clinical presentation, ${ }^{(29)}$ might have influenced this finding.

In response to difficulties in adherence to tuberculosis treatment and to avoid significant consequences on the outcomes of subsequent treatment, some strategies have been adopted with the aim of influencing the behavior of health professionals and the organization of health care services, as well as the behavior of those suspected of or diagnosed with tuberculosis. ${ }^{(30)}$ Although still very controversial, the DOTS strategy launched by the World Health Organization has achieved positive results, aiding in the control of the disease in various parts of the world..$^{(5,30)}$ In our study population, the OR for death from tuberculosis was lower among the patients who received DOTS, indicating that DOTS reduced the OR for the occurrence of negative tuberculosis outcomes.

Therefore, unfavorable tuberculosis treatment outcomes were not found to be related to the characteristics of tuberculosis in our study. Treatment abandonment and death were associated mainly with sociodemographic characteristics and health history.

We believe that, for Brazil, a country that has a comprehensive and recognized tuberculosis control program, our data indicate the importance of sociodemographic characteristics for the diagnosis of tuberculosis in patients with CKD and underscore the need for tuberculosis control strategies targeting certain population groups, with special priority for patients with chronic noncommunicable diseases, such as CKD. 
The outcome of tuberculosis treatment in subjects with chronic kidney disease in Brazil: a multinomial analysis

\section{References}

1. Saran R, Shahinian V. CKD: a pandemic calling for concerted public health action. Adv Chronic Kidney Dis. 2010;17(3):213-4. http://dx.doi.org/10.1053/j. ackd.2010.03.009 PMid:20439089

2. Eggers PW. The aging pandemic: demographic changes in the general and end-stage renal disease populations. Semin Nephrol. 2009;29(6):551-4. http://dx.doi.org/10.1016/j. semnephrol.2009.07.001 PMid:20006786

3. Donnelly PK, Shenton BK, Alomran AM, Francis DM, Proud G, Taylor RM. A new mechanism of humoral immunodepression in chronic renal failure and its importance to dialysis and transplantation. Proc Eur Dial Transplant Assoc. 1983;20:297-304. PMid:6361742

4. Bedendo J, Giarola LB, Moreira RR, Rossi RM, Borelli SD. Infections in patients with chronic renal failure and kidney transplant recipients in Brazil. Prog Transplant. 2011;21(3):249-53. PMid:21977886

5. Lawn SD, Zumla Al. Tuberculosis. Lancet. 2011;378(9785):57-72. http://dx.doi.org/10.1016/ S0140-6736(10)62173-3

6. Raviglione M, Marais B, Floyd K, Lönnroth K, Getahun $\mathrm{H}$, Migliori GB, et al. Scaling up interventions to achieve global tuberculosis control: progress and new developments. Lancet. 2012;379(9829):1902-13. Erratum in: Lancet. 2012;379(9833):2242. http://dx.doi.org/10.1016/ S0140-6736(12)60727-2

7. de Oliveira GP, Torrens AW, Bartholomay P, Barreira D. Tuberculosis in Brazil: last ten years analysis - 20012010. Braz J Infect Dis. 2013;17(2):218-33. http:// dx.doi.org/10.1016/j.bjid.2013.01.005 PMid:23474189

8. Barreto ML, Teixeira MG, Bastos Fl, Ximenes RA, Barata $\mathrm{RB}$, Rodrigues LC. Successes and failures in the control of infectious diseases in Brazil: social and environmental context, policies, interventions, and research needs. Lancet. 2011;377(9780):1877-89. http://dx.doi.org/10.1016/ S0140-6736(11)60202-X

9. Barros MB, Francisco PM, Zanchetta LM, César CL. Trends in social and demographic inequalities in the prevalence of chronic diseases in Brazil. PNAD: 2003-2008 [Article in Portuguese]. Cien Saude Colet. 2011;16(9):3755-68. http://dx.doi.org/10.1590/S1413-81232011001000012 PMid:21987319

10. Schmidt Ml, Duncan BB, Azevedo e Silva G, Menezes AM, Monteiro CA, Barreto SM, et al. Chronic non-communicable diseases in Brazil: burden and current challenges. Lancet. 2011;377(9781):1949-61. http://dx.doi.org/10.1016/ S0140-6736(11)60135-9

11. Laguardia J, Domingues CM, Carvalho C, Lauerman CR, Macário E, Glatt R. Sistema de Informação de Agravos de Notificação (Sinan): desafios no desenvolvimento de um sistema de informação em saúde. Epidemiol Serv Saude. 2004;13(3):135-47.

12. Medeiros D, Sucupira ED, Guedes RM, Costa AJ. Análise da qualidade das informações sobre tuberculose no município de Belford Roxo, Rio de Janeiro, 2006 a 2008. Cad Saude Colet. 2012;20(2):146-52.

13. Biesheuvel CJ, Vergouwe Y, Steyerberg EW, Grobbee DE, Moons KG. Polytomous logistic regression analysis could be applied more often in diagnostic research. J Clin Epidemiol. 2008;61(2):125-34. http://dx.doi. org/10.1016/j.jclinepi.2007.03.002 PMid:18177785
14. Maciel EL. Determinantes sociais da tuberculose: elementos para a ação. Promoção da saúde na diversidade humana e nos itinerários terapêuticos. Campinas: Saberes; 2012.

15. Victora CG, Huttly SR, Fuchs SC, Olinto MT. The role of conceptual frameworks in epidemiological analysis: a hierarchical approach. Int J Epidemiol. 1997;26(1):224-7. http://dx.doi.org/10.1093/ije/26.1.224 PMid:9126524

16. Khan MA, Chandrasekaran B, Needle M. Tuberculosis in chronic renal failure. Arch Intern Med. 1981;141(11):1554. http://dx.doi.org/10.1001/archinte.1981.00340120162037 PMid:7283574

17. Lezaic V, Radivojevic R, Radosavljevic G, Blagojevic R, Djukanovic L, Simic S, et al. Does tuberculosis after kidney transplantation follow the trend of tuberculosis in general population? Ren Fail. 2001;23(1):97-106. http:// dx.doi.org/10.1081/JDl-100001289 PMid:11256535

18. Venkata RK, Kumar S, Krishna RP, Kumar SB, Padmanabhan S, Kumar S. Tuberculosis in chronic kidney disease. Clin Nephrol. 2007;67(4):217-20. PMid:17474557

19. Malhão TA, Oliveira GP, Codennoti SB, Moherdaui F. Avaliação da completitude do Sistema de Informação de Agravos de Notificação da Tuberculose, Brasil, 20012006. Epidemiol Serv Saude. 2010;19(3):245-56.

20. Selig L, Kritski AL, Cascão AM, Braga JU, Trajman A, de Carvalho RM. Proposal for tuberculosis death surveillance in information systems. Rev Saude Publica. 2010;44(6):1072-8. http://dx.doi.org/10.1590/S003489102010000600012 PMid:21107505

21. Zhang X, Andersen AB, Lillebaek T, Kamper-Jørgensen $Z$, Thomsen VØ, Ladefoged K, et al. Effect of sex, age, and race on the clinical presentation of tuberculosis: a 15-year population-based study. Am J Trop Med Hyg. 2011;85(2):285-90. http://dx.doi.org/10.4269/ ajtmh.2011.10-0630 PMid:21813849 PMCid:PMC3144827

22. Pérez-Guzmán C, Vargas MH. Diabetes, aging, and tuberculosis. Lung India. 2011;28(3):191-2. http:// dx.doi.org/10.4103/0970-2113.83976 PMid:21886954 PMCid:PMC3162757

23. Silva FV, Avesani CM, Scheeffer C, Lemos CCS, Vale B, Silva MIB, et al. Tratamento da doença renal crônica: estratégias para o maior envolvimento do paciente em seu auto-cuidado. J Bras Nefrol. 2008;30(2):83-7.

24. Waitt CJ, Squire SB. A systematic review of risk factors for death in adults during and after tuberculosis treatment. Int J Tuberc Lung Dis. 2011;15(7):871-85. http://dx.doi. org/10.5588/ijtld.10.0352 PMid:21496360

25. Ahmad Khan F, Minion J, Al-Motairi A, Benedetti A, Harries $A D$, Menzies D. An updated systematic review and metaanalysis on the treatment of active tuberculosis in patients with HIV infection. Clin Infect Dis. 2012;55(8):1154-63. http://dx.doi.org/10.1093/cid/cis630 PMid:22820541

26. Reyes H, Coninx R. Pitfalls of tuberculosis programmes in prisons. BMJ. 1997;315(7120):1447-50. http://dx.doi. org/10.1136/bmj.315.7120.1447

27. Baussano 1, Williams BG, Nunn P, Beggiato M, Fedeli U, Scano F. Tuberculosis incidence in prisons: a systematic review. PLoS Med. 2010;7(12):e1000381. http://dx.doi. org/10.1371/journal.pmed.1000381 PMid:21203587 PMCid:PMC3006353

28. Oliveira HB, Moreira Filho DC. Treatment abandonment and tuberculosis recurrence: aspects of previous episodes, Brazil, 1993-1994 [Article in Portuguese]. Rev Saude Publica. 2000;34(5):437-43. http://dx.doi.org/10.1590/ S0034-89102000000500002 PMid:11105106 
29. Portillo-Gómez L, Morris SL, Panduro A. Rapid and efficient detection of extra-pulmonary Mycobacterium tuberculosis by PCR analysis. Int J Tuberc Lung Dis. 2000;4(4):361-70. PMid:10777087
30. Volmink J, Garner P. Directly observed therapy for treating tuberculosis. Cochrane Database Syst Rev. 2007;(4):CD003343. PMid:17943789

\section{About the authors}

\section{Barbara Reis-Santos}

Collaborator. Epidemiology Laboratory, Federal University of Espírito Santo, Vitória, Brazil.

\section{Teresa Gomes}

Collaborator. Epidemiology Laboratory, Federal University of Espírito Santo, Vitória, Brazil.

\section{Bernardo Lessa Horta}

Associate Professor. Federal University of Pelotas, Pelotas, Brazil.

\section{Ethel Leonor Noia Maciel}

Adjunct Professor. Federal University of Espírito Santo, Vitória, Brazil. 